\title{
Protein Fractions from Korean Mistletoe (Viscum Album coloratum) Extract Induce Insulin Secretion from Pancreatic Beta Cells
}

\author{
Ki-Wook Kim, ${ }^{1,2}$ Seung-Hoon Yang, ${ }^{1,3}$ and Jong-Bae Kim ${ }^{1}$ \\ ${ }^{1}$ School of Life Sciences, Handong Global University, Pohang, Gyungbuk 791-708, Republic of Korea \\ ${ }^{2}$ Department of Microbial Pathogenesis, Boyer Center for Molecular Medicine, Yale University School of Medicine, \\ New Haven, CT 06510, USA \\ ${ }^{3}$ Department of Biological Chemistry, The Weizmann Institute of Science, 76100 Rehovot, Israel
}

Correspondence should be addressed to Jong-Bae Kim; jbkim@handong.edu

Received 23 February 2014; Accepted 22 April 2014; Published 14 May 2014

Academic Editor: Cicero L. T. Chang

Copyright (C) $2014 \mathrm{Ki}$-Wook Kim et al. This is an open access article distributed under the Creative Commons Attribution License, which permits unrestricted use, distribution, and reproduction in any medium, provided the original work is properly cited.

\begin{abstract}
Mistletoe (Viscum Album coloratum) has been known as a medicinal plant in European and Asian countries. Recent data show that biological activity of mistletoe alleviates hypertension, heart disease, renal failure, and cancer development. In this study, we report the antidiabetic effect of Korean mistletoe extract (KME). KME treatments enhanced the insulin secretion from the pancreatic $\beta$-cell without any effects of cytotoxicity. PDX-1 and beta2/neuroD known as transcription factors that regulate the expression of insulin gene were upregulated by treatment of the KME protein fractions isolated by ion-exchange chromatography after ammonium sulfate precipitation. Furthermore, these KME protein fractions significantly lowered the blood glucose level and the volume of drinking water in alloxan induced hyperglycemic mice. Taken together with the findings, it provides new insight that KME might be served as a useful source for the development of medicinal reagent to reduce blood glucose level of type I diabetic patients.
\end{abstract}

\section{Introduction}

Insulin is an essential hormone that maintains the blood and urinary glucose level. At transcriptional level, insulin gene expression is controlled by the specific transcription factors: pancreatic and duodenal homeobox factor-1 (PDX-1) and beta2/neuroD [1-4]. However, abnormal immune response destroys pancreatic $\beta$ cell and impairs insulin secretion, leading to insulin dependent type I diabetes $[5,6]$. It leads to severe complications such as vascular disease, renal failure, and heart disease [7-9]. Although exogenous insulin therapy through the insulin pump or subcutaneous insulin injection temporally delays the onset of complications, it finally results in type I diabetes mellitus [10-13].

Mistletoe (Viscum album) is a semiparasitic plant which grows on deciduous trees in Asian and European countries.
It has been used as a traditional therapeutic reagent to lower blood pressure and modulate immune responses [14-18]. Previously, we reported that Korean mistletoe has a variety of immunological activities such as cytokine induction, NK cell activation, and adjuvant activity [19-21]. Specifically, lectins isolated from KME had antitumor activity to suppress tumor growth and to inhibit tumor-induced angiogenesis or metastasis [22-24]. Although it has been reported that KME and its lectins played critical role for immunological activity and antitumor activity [25], little is known about the antidiabetic effect of Korean mistletoe.

In this study, we revealed KME protein fractions without cellular damage induced to release insulin from the pancreatic $\beta$ cell by activating transcription factors such as PDX-1 and beta2/neuroD required for insulin gene expression. Possibly, due to the elevation of insulin release by $\mathrm{KME}$ protein 
fraction, the blood glucose level and drinking water volume were significantly reduced in alloxan induced hyperglycemic mice $[26,27]$.

\section{Materials and Methods}

2.1. Reagents. RPMI 1640 without glucose, alloxan, and Krebs-Ringer bicarbonate (KRB) buffer were purchased from Sigma. Anti-PDX-1 and antineuroD, all from Santa Cruz Biotechnology, were used for immunoblotting. Rat insulin ELISA Kit (SHIBAYAGI) was used for insulin secretion. SYBR green master mix (Applied Biosystems) and RNA Easyspin (iNtRON) were used for real-time PCR.

2.2. Cell Culture and Treatment. Rat pancreatic $\beta$ cells, RINm5F cells, were provided by Pohang University of Science and Technology (POSTECH). RINm5F cells were cultured in a monolayer in RPMI 1640 medium (Gibco) supplemented with $10 \%$ fetal bovine serum (FBS, CAMBREX), $1 \%$ penicillin/streptomycin (CAMBREX), and $5.5 \mathrm{mM}$ glucose at $37^{\circ} \mathrm{C}$ under a humidified $95 \%-5 \%(\mathrm{v} / \mathrm{v})$ mixture of air and $\mathrm{CO}_{2}$. RINm5F cells were cultured in complete medium with $10 \%$ FBS to $\sim 90 \%$ cell confluence and were then incubated with $0.5 \%$ FBS medium for $12 \sim 16$ hours. After that, RINm5F cells were treated with KM extract. The supernatant was used for detection of insulin secretion and the attached cells were used for immunoblotting.

2.3. Animals. Specific pathogen-free 7-week-old imprinting control region (ICR) mouse strains were purchased from the Dae-Han Laboratory Animal Center, Republic of Korea. Mice were maintained in the Laboratory of Animal Experiment, Institute of Bioscience, Han-Dong Global University, under laminar air-flow conditions. Water and diets were supplied ad libitum. Each group was composed of 5 mice for checking blood glucose level and drinking water volumes.

2.4. Extraction and Purification of Korean Mistletoe. Mistletoe growing on oak (Quercus variabilis Blume) between December and February was harvested from Kangwon-do, Korea, and stored at $-80^{\circ} \mathrm{C}$ until use. The nonlectin fractions (NLF) were isolated from an extract of Korean mistletoe plants using hydrolyzed $\alpha$-lactose-Sepharose (Sigma) column chromatography after ammonium sulfate precipitation as described previously $[24,25]$. Briefly, the extracts were dissolved in distilled water and filtered through a $0.45 \mu \mathrm{m}$ membrane (Whatmann). Then, they adjusted to $70 \%$ saturation with $\left(\mathrm{NH}_{4}\right) \mathrm{SO}_{4}$. The precipitate was resuspended in a small volume of phosphate-buffered saline (PBS), dialyzed against the same buffer, and applied to an $\alpha$-lactose-Sepharose column which had been hydrolyzed for 2.5 hours. To remove the Korean mistletoe lectin (KML-C), the adsorbed material was eluted with a lactose-containing buffer ( $0.1 \mathrm{M}$ lactose, $\mathrm{pH}$ 7.3). Unbounded proteins which were free of KML-C were pooled, dialyzed against distilled water, and freeze-dried. Each process was performed at $4^{\circ} \mathrm{C}$. NLF dissolved in distilled water was partitioned by chloroform. Chloroformic extracts dissolved in phosphate buffer (PBS, $10 \mathrm{mM}$ phosphate buffer containing $0.85 \% \mathrm{NaCl}, \mathrm{pH} 7.4$ ) were applied to the DEAESepharose Fast flow column (Amersham Pharmacia Biotech.) which had previously equilibrated with the same buffer. After column was washed with phosphate buffer again, remaining bound proteins were eluted with $0.5 \mathrm{M}, 1 \mathrm{M}$, and $2 \mathrm{M} \mathrm{NaCl}$ (DEAE $0.5 \mathrm{M}, 1 \mathrm{M}$, and $2 \mathrm{M}$ fractions). DEAE fractions dissolved in PBS were applied to the Sep-Pak column (Waters Corporation) which had been previously equilibrated with the same buffer. The column was washed with PBS, and bound proteins were eluted with $20 \%$ ethanol (Sep-Pak 20\%, SP20 fractions) and 60\% ethanol (Sep-Pak 60\%, SP60 fractions). Each eluted protein fraction was dialyzed against distilled water every 4 hours for 3 days and stored in $-20^{\circ} \mathrm{C}$ until use.

2.5. FACS Analysis for Cytotoxicity. Cytotoxicity was analyzed by the annexin $\mathrm{V}$ and propidium iodide (PI, Merck) using flow-cytometry (FACS) machine (Beckman Coulter Epic XL). RINm5F cells $\left(2 \times 10^{6}\right.$ cells $)$ were seeded into 6-well plates and incubated for 12 hours. After washing, KM extract was treated with the cells and incubated in the $37^{\circ} \mathrm{C}$ with $5 \%$ $\mathrm{CO}_{2}$ for 30 minutes. Cells were carefully detached from the plates, and then detached cells were stained with the apoptosis detection kit containing annexin V-FITC and PI at ice in the dark condition. Stained cells were washed with FACS solution and living or dead cells were measured by FACS machine.

2.6. Measurement of Insulin. $1 \mathrm{~mL}$ of RINm5F cells $(4 \times$ $10^{5}$ cells/well) was seeded into the 24 -well plates (Falcon) and cultured in RPMI-1640 containing 11.1 mM glucose (Sigma). After incubation for $12 \mathrm{hr}$ to allow attachment, cells were washed with Krebs-Ringer bicarbonate buffer (KRB) in 3 times. Then, cells were preincubated with $1 \mathrm{~mL}$ of KRB buffer for 30 minutes at $37^{\circ} \mathrm{C}$. Cells were then incubated for 30 minutes with $\mathrm{KM}$ extracts. The supernatants were collected from each well and stored at $-20^{\circ} \mathrm{C}$ until use for insulin secretion assay. An assay for the measurement of insulin secretion from RINm5F cells was carried out by rat insulin ELISA Kit (SHIBAYAGI) and detected by ELISA reader at $450 \mathrm{~nm}$.

2.7. Real-Time PCR. Total RNA were extracted using easyspin RNA extraction kit (Intron, Korea). cDNA were produced with $5 \mu \mathrm{g}$ of total RNA using Superscript (Invitrogen). In a florescent temperature cycler (LightCycler; Roche Diagnostics Ltd., Lewes, UK), 10 percent of each RT reaction was amplified in a $20 \mu \mathrm{L}$ PCR containing $4 \mathrm{mM} \mathrm{MgCl}_{2}, 4 \mathrm{pmol}$ of each primer, and 1x SYBR green master mix. Samples were incubated in the LightCycler for an initial denaturation at $94^{\circ} \mathrm{C}$ for 30 seconds, followed by 30 PCR cycles. Each cycle consisted of $95^{\circ} \mathrm{C}$ for 15 seconds, $55^{\circ} \mathrm{C}$ for 32 seconds, and $72^{\circ} \mathrm{C}$ for 32 seconds.

\section{The Oligonucleotide Primers}

For insulin are forward: 5 '-ATA GAC CAT CAG CAA GCA GG-3', 

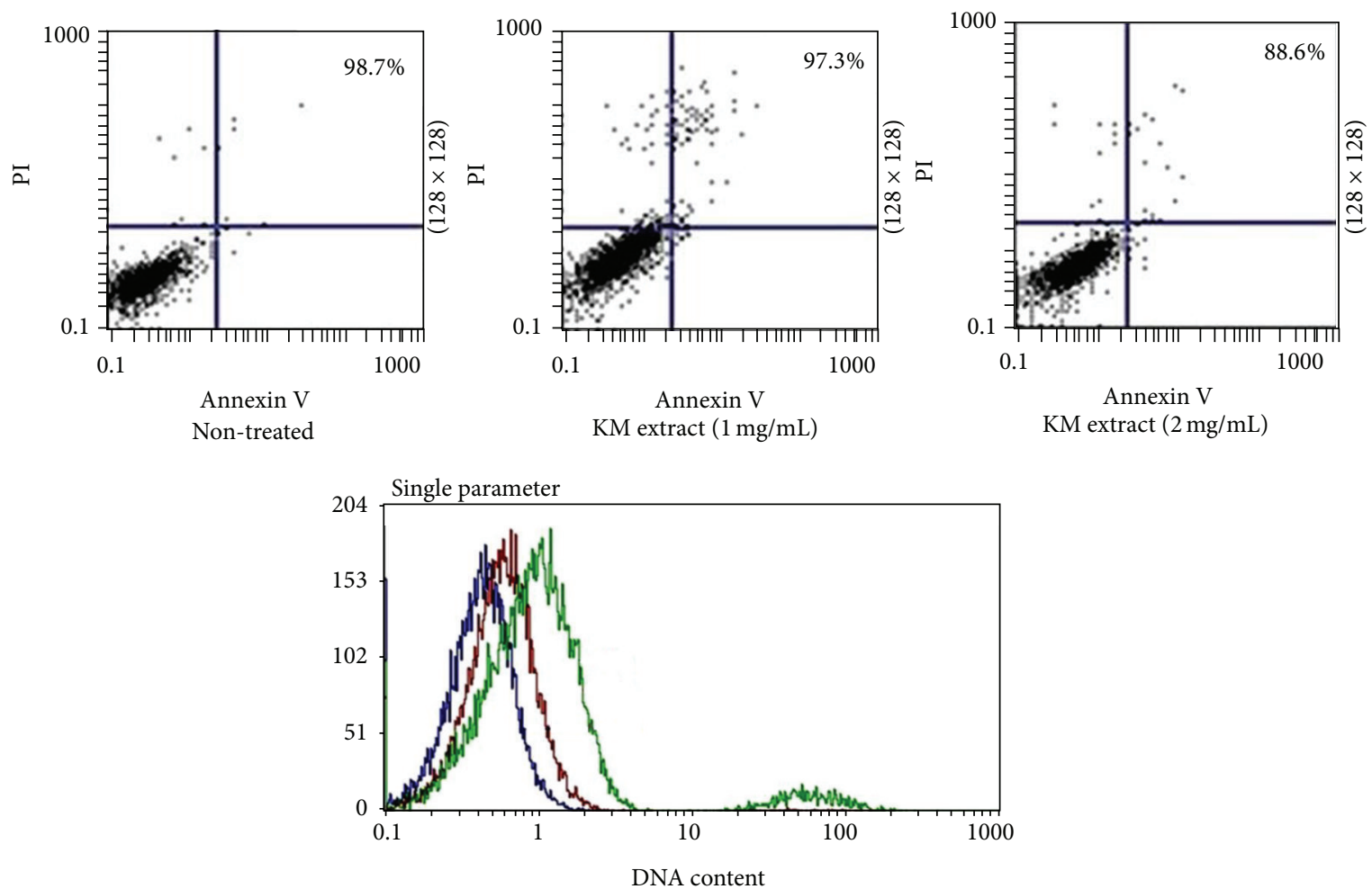

(a)

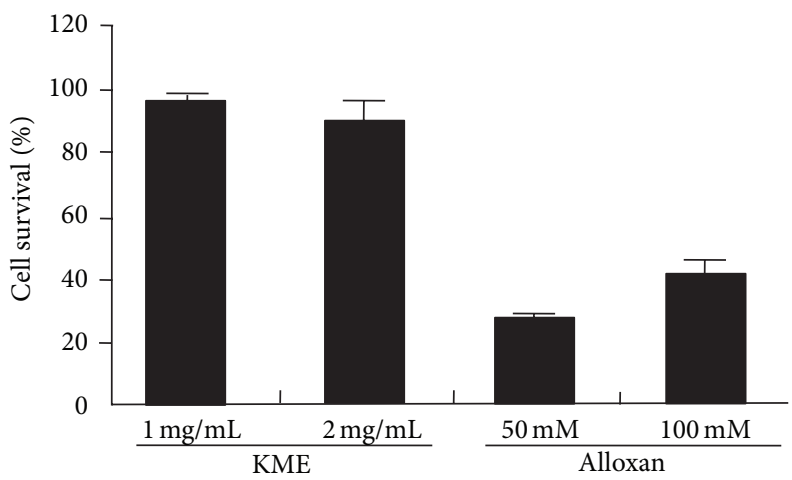

(b)

FIGURE 1: Cytotoxicity of pancreatic $\beta$ cells by KME treatment. (a) Representative FACS analysis for PI and annexin V staining of RINm5F cell following KME treatment. Nontreated RINm5F cells (left), KME ( $1 \mathrm{mg} / \mathrm{mL}$ ) treated RINm5F cell (middle), and KME $(2 \mathrm{mg} / \mathrm{mL})$ treated RINm5F cells (right). DNA contents of RINm5F cells under the KME treatment. Blue: nontreated, red: KME (1 mg/mL), and green: KME $(2 \mathrm{mg} / \mathrm{mL})$. (b) The cytotoxic activity of KME- or alloxan-treated cells was measured by XTT assay.

reverse: $5^{\prime}$-CTC CAG TTG TGG CAC TTG CG-3';

For PDX-1 are

forward: $5^{\prime}$-TAC GCG GCC ACA CAG CTC TAC AAG GAC-3',

reverse: $5^{\prime}$-CCA CTT CAT GCG ACG GTT TTG GAA CCA GA- $3^{\prime}$;

And for $\beta$-actin are

forward: $5^{\prime}$-AGG ATG CAG AAG GAG ATC ACT G-3', reverse: 5 '-GGG TGT AAC GCA ACT AAG TCA TAG- $3^{\prime}$.

$\beta$-actin was used as an endogenous internal control. To confirm amplification of specific transcripts, melting curve profiles (cooling the sample to $65^{\circ} \mathrm{C}$ for 15 seconds and heating slowly to $95^{\circ} \mathrm{C}$ with continuous measurement of fluorescence) were produced at the end of each PCR procedure.

2.8. Western Blot Analysis. For Western blotting analysis, cells were lysed by resuspension in buffer A $(25 \mathrm{mM}$ Tris$\mathrm{HCl}, \mathrm{pH} 7.5,2 \mathrm{mM}$ Na orthovanadate, $0.5 \mathrm{mM}$ EDTA, $10 \mathrm{mM}$ 


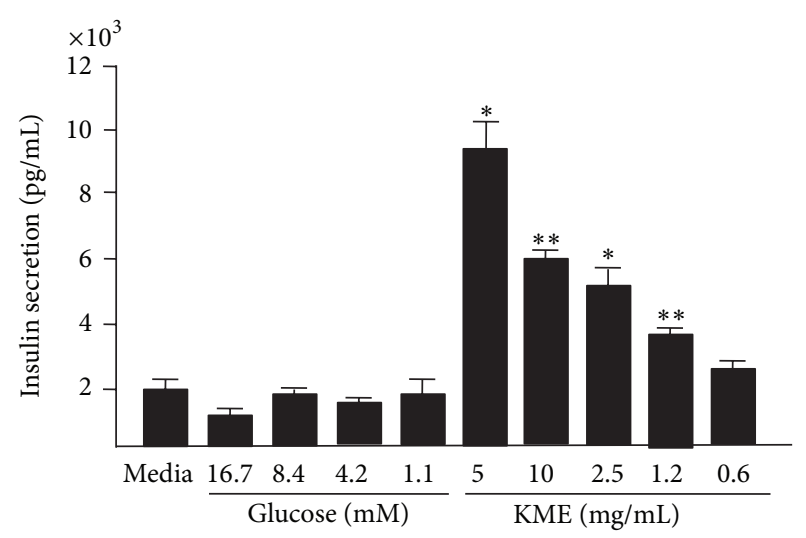

(a)

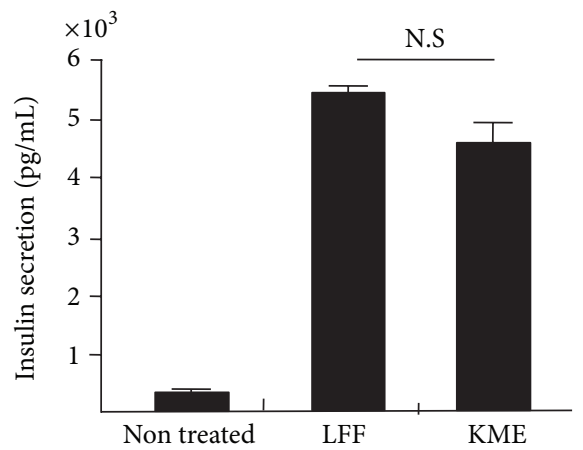

(c)

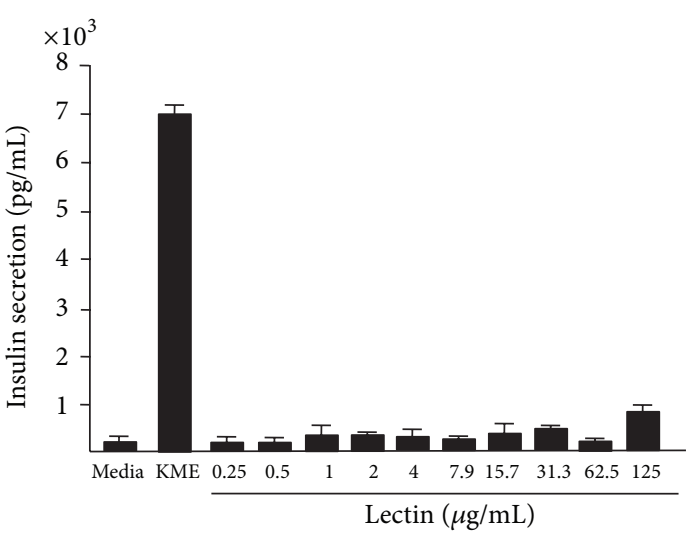

(b)

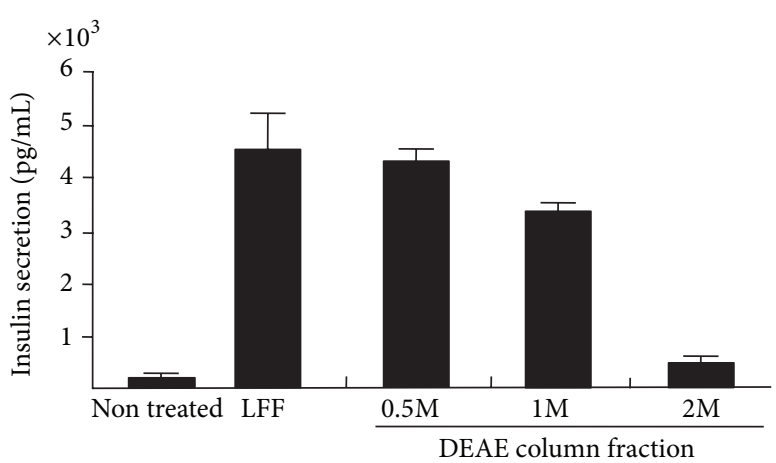

(d)

FIGURE 2: Insulin secretion of RINm5F cells by a variety of KME protein fractions. (a) Insulin secretion of RINm5F cell by KME dose dependent manner. (b) Insulin secretion of RINm5F cells by lectin (KML-C) isolated from Korean mistletoe. (c) Insulin secretion of RINm5F cells by the lectin-free KME and total KME. (d) Insulin secretion of RINm5F cells by protein fractions from KME isolated by ion-exchange chromatography.

$\mathrm{NaF}, 10 \mathrm{mM}$ Na pyrophosphate, $80 \mathrm{mM} \beta$-glycerophosphate, $25 \mathrm{mM} \mathrm{NaCl}, 1 \%(\mathrm{v} / \mathrm{v})$ Nonidet P-40) containing $1 \mathrm{x}$ complete protease inhibitor mixture (Roche Diagnostics) and then boiled for $10 \mathrm{~min}$. After sonication, they were centrifuged for $15 \mathrm{~min}$ in $13,000 \times \mathrm{g}$. Protein concentration in the extract was determined using the BCA kit (Pierce). Protein samples were separated on SDS-PAGE and blotted onto nitrocellulose membrane (Amersham Biosciences). Blots were developed with the ECL kit (Pierce).

2.9. Generation and Analysis of Hyperglycemic Mice. ICR mice were grouped into several groups of five mice. Alloxan $(70 \mathrm{mg} / \mathrm{kg})$ was injected into mice via tail vein. Next day of alloxan injection, $200 \mu \mathrm{L}$ of DEAE eluted protein fractions from KM extracts $(50,100,200$, and $400 \mu \mathrm{g} / \mathrm{mL})$ was injected intraperitoneally. After 10 days, the same volumes of DEAE eluted protein fraction were injected intraperitoneally again. Blood was obtained from the tail vein of injected mice through heparinized capillary tube. Blood glucose levels were measured by the glucose measurement kit (Assan Pharmacia). Drinking water volumes were measured by a decimeter.

\section{Results}

3.1. KME Has No Cytotoxicity to Rat Pancreatic $\beta$ Cell. Due to the cytotoxicity of lectin A subunit contained in KME, we examined whether KME has the cytotoxic activity on rat pancreatic $\beta$ cells (RINm5F). Apoptotic cells and necrotic cell were measured by annexin V and PI staining. As shown in Figure 1(a), most cells were alive after aqueous KM extract $(1 \mathrm{mg} / \mathrm{mL}, 2 \mathrm{mg} / \mathrm{mL})$ treatment. It indicates that RINm5 cell viability was not affected by KME treatment. To evaluate the cell proliferation as well as cytotoxicity, we incubated RINm5 cells with KME ( $1 \mathrm{mg} / \mathrm{mL}, 2 \mathrm{mg} / \mathrm{mL})$ for 48 hours. The survival rate of RINm5 cell was measured by XTT assay. Well known as a chemical compound to specifically destroy pancreatic beta cells, alloxan severely damaged the RINm5 cells. However, RINm5 cells were not affected by KME at all (Figure 1(b)). These findings imply that KME is not toxic to the rat pancreatic $\beta$ cells.

3.2. Lectin-Free KME Protein Fractions Induce Insulin Secretion on Rat Pancreatic $\beta$ Cell. To examine the potential to secrete insulin by KME, the insulin released from RINm5F 


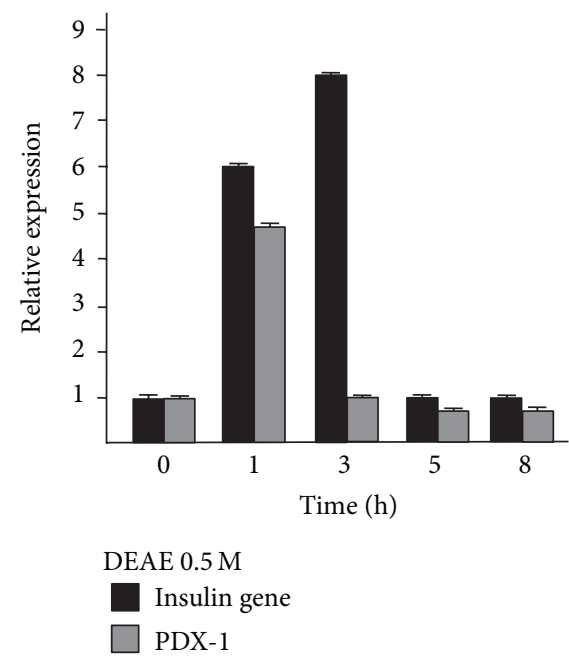

(a)

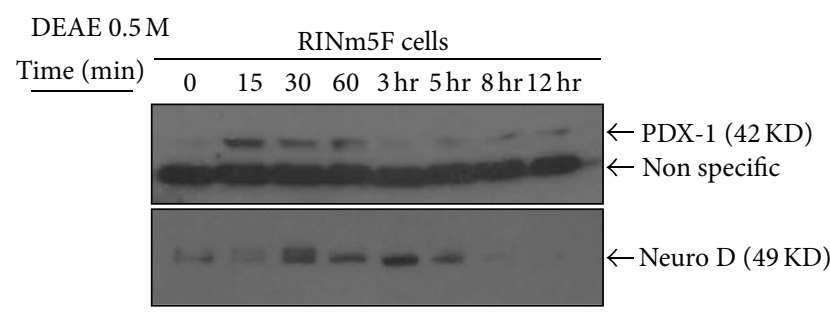

(c)

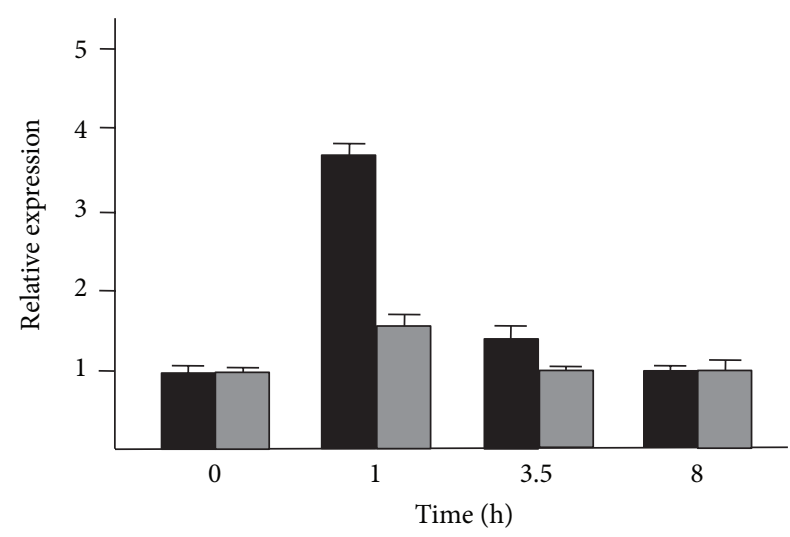

DEAE $1 \mathrm{M}$

Insulin gene

PDX-1

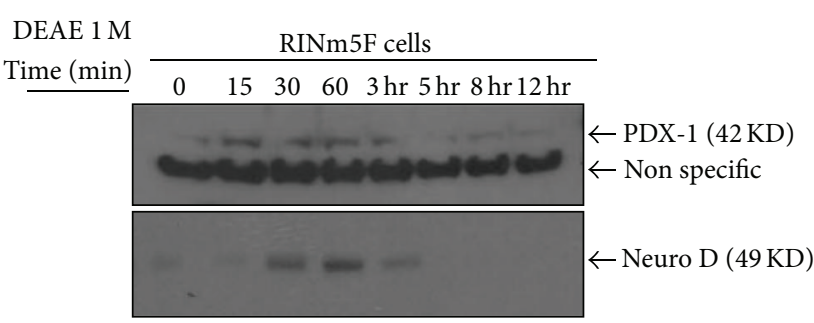

(d)

FIGURE 3: Insulin gene and transcription factor expression by DEAE-Sepharose fractionated KME protein fractions. ((a)-(b)) Time dependent mRNA expressions of insulin gene and PDX-1 gene in RINm5F cells under the treatment of (a) $0.5 \mathrm{M}$ DEAE protein fractions and (b) $1 \mathrm{M}$ DEAE. ((c)-(d)) Time dependent PDX-1 and beta2/neuroD protein expressions of RINm5F cells under the treatment of (d) 0.5 M DEAE protein fraction and (d) $1 \mathrm{M}$ DEAE protein fraction.

cells was measured by ELISA after treatment of a several doses of KME. While glucose concentration had no effect to secrete insulin, KME had stimulatory effect on insulin secretion in a dose dependent manner (Figure 2(a)). Next, we investigated whether the lectin (KML-C) isolated from KME has potential to secrete insulin on RINm5F cells. Although the lectin (KML-C) isolated by KME was treated with the RINm5 cells in a dose dependent manner (0.25 $125 \mu \mathrm{g} / \mathrm{mL}$ ) for 12 hours, insulin secretion was not detected in RINm5F cells (Figure 2(b)). However, lectin-free KME protein fraction (LFF) induced insulin secretion as similar as the KME treatments (Figure 2(c)). Thereafter, LFF was isolated from DEAE-Sepharose Column and finally divided into three fractions by concentration of $0.5 \mathrm{M}, 1 \mathrm{M}$, and $2 \mathrm{M}$ $\mathrm{NaCl}$ elution buffer, respectively. Both $0.5 \mathrm{M}$ and $1 \mathrm{M} \mathrm{NaCl}$ eluted DEAE-Sepharose column fractions induced insulin secretion from RINm5F cells whereas $2 \mathrm{M} \mathrm{NaCl}$ eluted DEAE-Sepharose column fractions did not have insulin secretion ability (Figure 2(d)). Therefore, it suggested that purified protein factions from KME have an ability of insulin induction in rat pancreatic $\beta$ cells.

3.3. Protein Fractions from KME Induce Insulin and PDX-1 Gene Expression. The molecular mechanism of insulin secretion by protein fraction of KME remains unknown. To determine whether protein fractions of KME activate insulin gene in transcriptional levels, we analyzed the expression level of insulin gene and its related transcription factor, PDX-1, through the real-time PCR. After the treatment of $0.5 \mathrm{M}$ DEAE protein fractions, insulin genes were peaked at three hours and PDX-1 genes were upregulated in an hour (Figure 3(a)). Although insulin genes and PDX-1 genes in $1 \mathrm{M}$-DEAE protein fraction treated RINm5F cells were relatively shown in low expression, they were also upregulated in an hour (Figure 3(b)).

Although the expression level of PDX-1 genes was not altered within $60 \mathrm{~min}$, the expression level of insulin genes was significantly increased in real-time PCR analysis. To address this discrepancy, we determined to analyze the PDX1 and beta2/neuroD expression in time dependent manner. Western analysis of PDX-1 expression revealed that this transcription factor was highly increased after $15 \mathrm{~min}$ of $0.5 \mathrm{M}$ or $1 \mathrm{M}$ DEAE protein fraction of KME treatment and its expression was gradually decreased. Similar to the PDX-1, beta2/neuroD is highly expressed within $60 \mathrm{~min}$ by the $0.5 \mathrm{M}$ or $1 \mathrm{M}$ DEAE protein fraction of KME (Figures 3(c) and 3(d)). These results strongly suggested that protein fractions of KME activate PDX-1 and beta2/neuroD transcription factors 


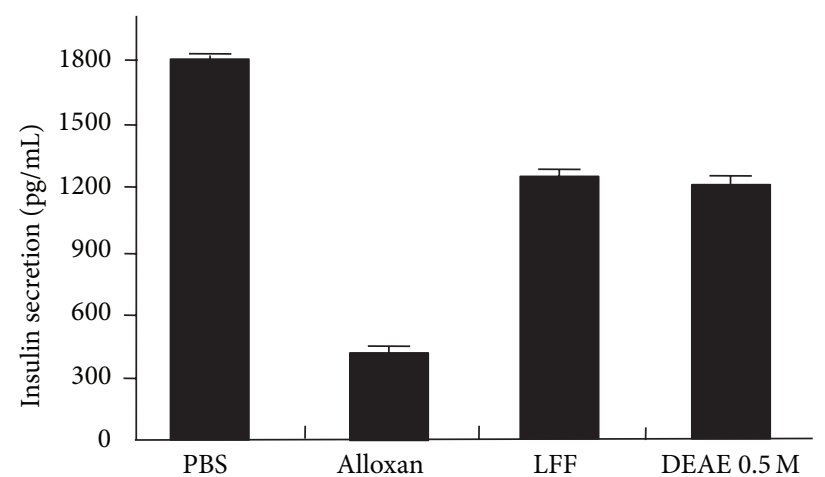

(a)

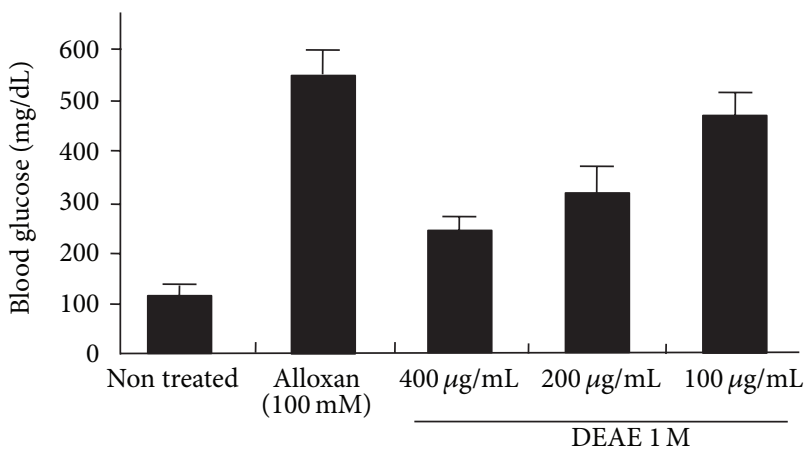

(c)

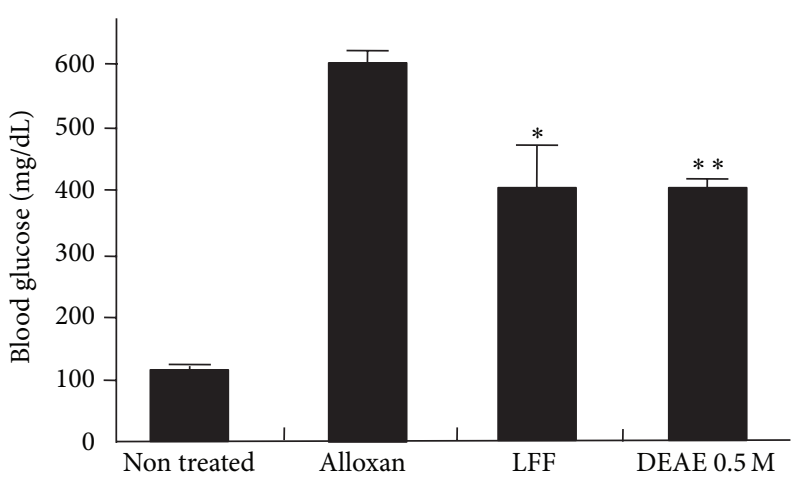

(b)

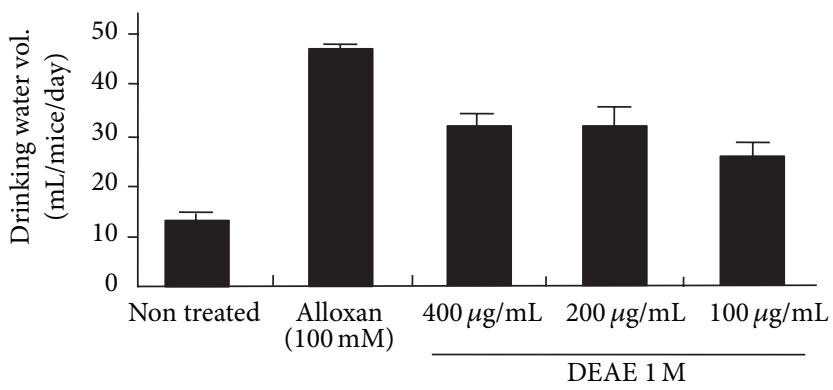

(d)

FIGURE 4: Antidiabetic effect of KME protein fractions on alloxan induced hyperglycemic mice. ((a)-(b)) Restoration of (a) insulin level and (b) blood glucose level of alloxan induced hyperglycemic mice by the lectin-free KME and 0.5 M DEAE protein fraction of KME. (c) Restoration of blood glucose level of alloxan induced mice by dose dependent $1 \mathrm{M}$ DEAE protein fractions. (d) Reduction of drinking-water consumption of alloxan induced mice by $1 \mathrm{M}$ DEAE protein fractions.

in early time point, eventually resulting in the activation of insulin gene.

\subsection{Protein Fractions from KME Rescued the Insulin Secretion and Blood Glucose Level in Alloxan Induced Hyperglycemic} Mice. Next, we examined whether insulin secretion and blood glucose level could be rescued by introduction of the protein fractions of KME in vivo model. To this end, lectinfree fraction of KME or its $0.5 \mathrm{M}$ DEAE protein fraction was injected into alloxan induced diabetic mice, respectively. Insulin secretion and serum glucose level were measured after 48 hours of KME fractionated protein injection. We found that insulin secretion was severely impaired by alloxan injection but it was partially restored by injection of the KME protein fractions (Figure 4(a)). Furthermore, blood glucose level was restored by $0.5 \mathrm{M}$ DEAE protein fraction treated mice, compared to alloxan treated mice (Figure 4(b)). Also, it was confirmed that blood glucose level of alloxan induced diabetic mice was gradually reduced by dose dependent manner of $1 \mathrm{M}$ DEAE protein fraction treatment (Figure 4(c)).

Similar to diabetic patients, alloxan induced diabetic mice consumed much more water than normal mice. To investigate whether the consumption of drinking water could be reduced by treatment of DEAE protein fractions of $\mathrm{KME}$, we measured the volume of drinking water of diabetic mice in the presence or absence of DEAE protein fractions of KME. As expected, drinking water volume was slightly decreased regardless of the dose of DEAE protein fractions (Figure 4(d)). Collectively, these findings suggested that DEAE-Sepharose fractionated proteins from KM extract have an effective antidiabetic activity in alloxan induced hyperglycemia mice.

\section{Discussion}

It has been well known that Korean mistletoe has strong immunomodulatory effects such as immune cells activation, cytokines induction, and antitumor effects [19, 20, 22-24]. Despite the use of this plant as an effective traditional treatment for diabetes, little is known about the molecular mechanism for the antidiabetic effect of this plant [28].

In this study, we demonstrated the antidiabetic effect of the various KME protein fractions in vitro and in vivo molecular mechanisms of insulin secretion. First, we examined the induction ability of insulin secretion from pancreatic $\beta$ cells by various protein fractions of KME through the activation of transcription factors such as PDX-1 and beta2/neuroD which regulate the insulin genes expression. Second, we found that pancreatic $\beta$ cells were not impaired by KME treatment whereas these cells were severely destroyed by alloxan treatment. Our data support that KME directly activates the 
insulin genes and transcription factors associated with the insulin gene expression for the first time.

Initially, it has been expected that lectin of Korean mistletoe (KML-C) could have an effect on diabetes because of its diverse biological activities. However, the data showed in this study that KML-C is not related to the induction of insulin and lectin-free KME protein fractions (LFF) stimulate the secretion of insulin. Furthermore, we investigated the fact that protein fractions from KME separated by several purification methods induce insulin secretion from rat pancreatic $\beta$ cells. Molecular signaling of insulin induction was controlled by activation of several transcription factors. Here, we demonstrated that PDX-1 and beta2/neuroD, which play a critical role in induction of insulin genes expression, were upregulated in KME treated pancreatic $\beta$-cells. Consistent with in vitro data, KME treatment restored the insulin secretion in alloxan induced hyperglycemic mice. Moreover, blood glucose level and drinking water volume were restored by KME treatment in alloxan induced hyperglycemic mice. These in vivo data support that $\mathrm{KME}$ is able to rescue destroyed pancreatic $\beta$ cells or delay the pancreatic $\beta$ cells destruction. As reported in Lyu et al., the lectin component of $\mathrm{KME}$ is able to promote cell proliferation [29]. Accordingly, we speculate that some specific components of KME regulate the proliferation or regeneration of pancreatic $\beta$ cells but its molecular mechanism will be investigated in the future.

In conclusion, the present study provides evidence for the first time for insulin releasing protein fractions in Korean mistletoe. It is required for separating a large amount of specific single peptide from KME which has an insulinsecreting activity. Together with the current findings, it is thought that this single peptide from KME can represent a source of potential new therapy for plant treatment of diabetes.

\section{Conflict of Interests}

The authors declare that there is no conflict of interests regarding the publication of this paper.

\section{Authors' Contribution}

Ki-Wook Kim and Seung-Hoon Yang contributed equally to this work.

\section{References}

[1] M. Welsh, D. A. Nielsen, A. J. MacKrell, and D. F. Steiner, "Control of insulin gene expression in pancreatic $\beta$-cells and in an insulin-producing cell line, RIN-5F cells. II. Regulation of insulin mRNA stability," The Journal of Biological Chemistry, vol. 260, no. 25, pp. 13590-13594, 1985.

[2] P. O. Berggren and I. B. Leibiger, "Novel aspects on signaltransduction in the pancreatic beta-cell," Nutrition, Metabolism \& Cardiovascular Diseases, vol. 16, supplement 1, pp. S7-S10, 2006.

[3] P. M. Jones and S. J. Persaud, "Protein kinases, protein phosphorylation, and the regulation of insulin secretion from pancreatic $\beta$-cells," Endocrine Reviews, vol. 19, no. 4, pp. 429-461, 1998.
[4] S. K. Chakrabarti and R. G. Mirmira, "Transcription factors direct the development and function of pancreatic $\beta$ cells," Trends in Endocrinology and Metabolism, vol. 14, no. 2, pp. 78$84,2003$.

[5] "Diagnosis and classification of diabetes mellitus," Diabetes Care, vol. 27, supplement 1, pp. S5-S10, 2004.

[6] E. J. Weringer and A. A. Like, "Immune attack on pancreatic islet transplants in the spontaneously diabetic BioBreeding/Worcester $(\mathrm{BB} / \mathrm{W})$ rat is not MHC restricted," Journal of Immunology, vol. 134, no. 4, pp. 2383-2386, 1985.

[7] W. T. Cade, "Diabetes-related microvascular and macrovascular diseases in the physical therapy setting," Physical Therapy, vol. 88 , no. 11, pp. 1322-1335, 2008.

[8] M. Brownlee, "Biochemistry and molecular cell biology of diabetic complications," Nature, vol. 414, no. 6865, pp. 813-820, 2001.

[9] A. R. Andersen, J. S. Christiansen, J. K. Andersen, S. Kreiner, and T. Deckert, "Diabetic nephropathy in type 1 (insulindependent) diabetes: an epidemiological study," Diabetologia, vol. 25, no. 6, pp. 496-501, 1983.

[10] D. E. deWitt and I. B. Hirsch, "Outpatient insulin therapy in type 1 and type 2 diabetes mellitus: scientific review," Journal of the American Medical Association, vol. 289, no. 17, pp. 2254-2264, 2003.

[11] Y. Ohkubo, H. Kishikawa, E. Araki et al., "Intensive insulin therapy prevents the progression of diabetic microvascular complications in Japanese patients with non-insulin-dependent diabetes mellitus: a randomized prospective 6-year study," Diabetes Research and Clinical Practice, vol. 28, no. 2, pp. 103117, 1995.

[12] M. A. Atkinson and G. S. Eisenbarth, "Type 1 diabetes: new perspectives on disease pathogenesis and treatment," The Lancet, vol. 358, no. 9277, pp. 221-229, 2001.

[13] S. C. Shah, J. I. Malone, and N. E. Simpson, "A randomized trial of intensive insulin therapy in newly diagnosed insulindependent diabetes mellitus," The New England Journal of Medicine, vol. 320, no. 9, pp. 550-554, 1989.

[14] G. Stein, W. Henn, H. von Laue, and P. Berg, "Modulation of the cellular and humoral immune responses of tumor patients by mistletoe therapy," European Journal of Medical Research, vol. 3, no. 4, pp. 194-202, 1998.

[15] J. Melzer, F. Iten, K. Hostanska, and R. Saller, "Efficacy and safety of mistletoe preparations (viscum album) for patients with cancer diseases," Forschende Komplementarmedizin, vol. 16, no. 4, pp. 217-226, 2009.

[16] A. M. Gray and P. R. Flatt, "Insulin-secreting activity of the traditional antidiabetic plant Viscum album (mistletoe)," Journal of Endocrinology, vol. 160, no. 3, pp. 409-414, 1999.

[17] B. Gerber, C. Scholz, T. Reimer, V. Briese, and W. Janni, "Complementary and alternative therapeutic approaches in patients with early breast cancer: a systematic review," Breast Cancer Research and Treatment, vol. 95, no. 3, pp. 199-209, 2006.

[18] E. C. Lavelle, G. Grant, A. Pusztai et al., "Mistletoe lectins enhance immune responses to intranasally co-administered herpes simplex virus glycoprotein D2," Immunology, vol. 107, no. 2, pp. 268-274, 2002.

[19] T. J. Yoon, Y. C. Yoo, T. B. Kang et al., "Cellular and humoral adjuvant activity of lectins isolated from Korean mistletoe (Viscum album colaratum)," International Immunopharmacology, vol. 1, no. 5, pp. 881-889, 2001. 
[20] T. J. Yoon, Y. C. Yoo, T. B. Kang et al., "Prophylactic effect of Korean mistletoe (Viscum album coloratum) extract on tumor metastasis is mediated by enhancement of NK cell activity," International Journal of Immunopharmacology, vol. 20, no. 4-5, pp. 163-172, 1998.

[21] T. J. Yoon, Y. C. Yoo, T. B. Kang et al., "Lectins isolated from Korean mistletoe (Viscum album coloratum) induce apoptosis in tumor cells," Cancer Letters, vol. 136, no. 1, pp. 33-40, 1999.

[22] T. J. Yoon, Y. C. Yoo, T. B. Kang et al., "Antitumor activity of the Korean mistletoe lectin is attributed to activation of macrophages and NK cells," Archives of Pharmacal Research, vol. 26, no. 10, pp. 861-867, 2003.

[23] T. J. Yoon, Y. C. Yoo, O. B. Choi et al., "Inhibitory effect of Korean mistletoe (Viscum album coloratum) extract on tumour angiogenesis and metastasis of haematogenous and non-haematogenous tumour cells in mice," Cancer Letters, vol. 97, no. 1, pp. 83-91, 1995.

[24] T. B. Kang, Y. C. Yoo, K. H. Lee et al., "Korean mistletoe lectin (KML-IIU) and its subchains induce nitric oxide (NO) production in murine macrophage cells," Journal of Biomedical Science, vol. 15, no. 2, pp. 197-204, 2008.

[25] T. B. Kang, S. K. Song, T. J. Yoon et al., "Isolation and characterization of two Korean mistletoe lectins," Journal of Biochemistry and Molecular Biology, vol. 40, no. 6, pp. 959-965, 2007.

[26] H.-W. Rho, J.-N. Lee, H.-R. Kim, B.-H. Park, and J.-W. Park, "Protective mechanism of glucose against alloxan-induced $\beta$ cell damage: pivotal role of ATP," Experimental and Molecular Medicine, vol. 32, no. 1, pp. 12-17, 2000.

[27] B.-H. Park and J.-W. Park, "The protective effect of Amomum xanthoides extract against alloxan-induced diabetes through the suppression of $\mathrm{NF} \kappa \mathrm{B}$ activation," Experimental and Molecular Medicine, vol. 33, no. 2, pp. 64-68, 2001.

[28] T. Mandrup-Poulsen, "Apoptotic signal transduction pathways in diabetes," Biochemical Pharmacology, vol. 66, no. 8, pp. 14331440, 2003.

[29] S. Y. Lyu, J. H. Choi, H. J. Lee, W. B. Park, and G. J. Kim, "Korean mistletoe lectin promotes proliferation and invasion of trophoblast cells through regulation of Akt signaling," Reproductive Toxicology, vol. 39, pp. 33-39, 2013. 


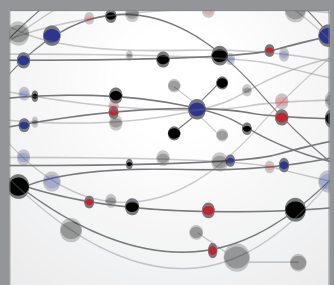

The Scientific World Journal
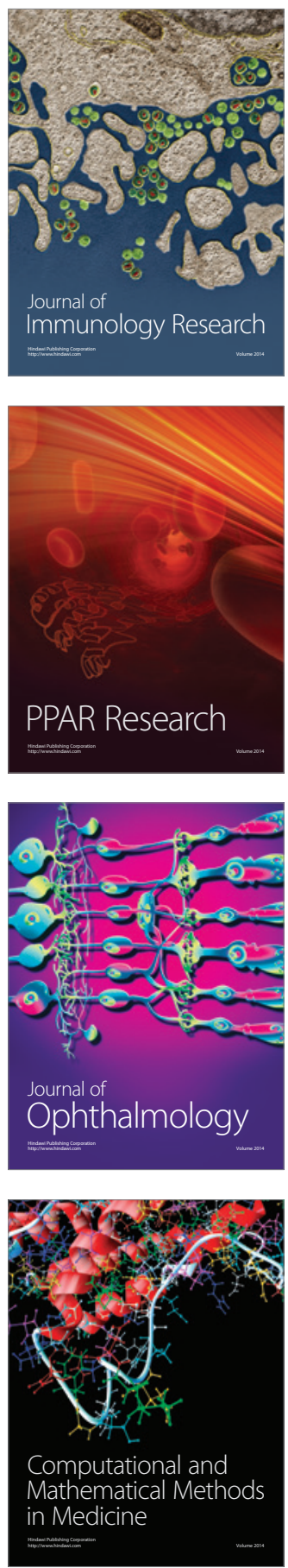

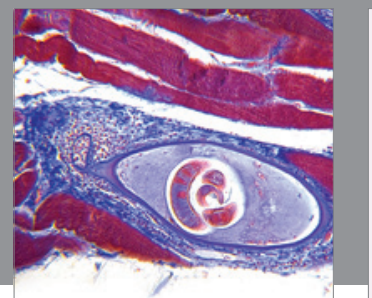

Gastroenterology

Research and Practice
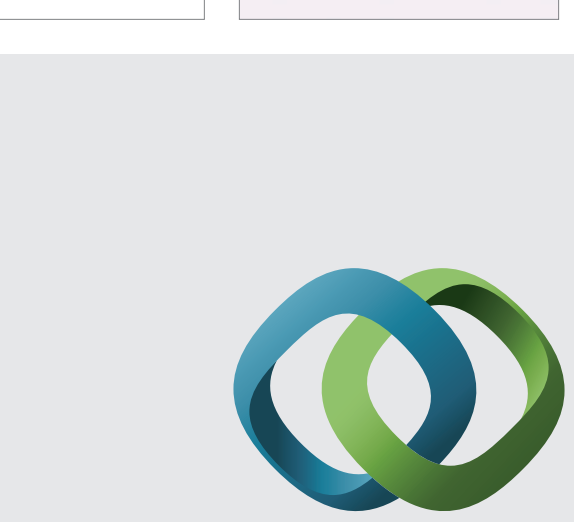

\section{Hindawi}

Submit your manuscripts at

http://www.hindawi.com
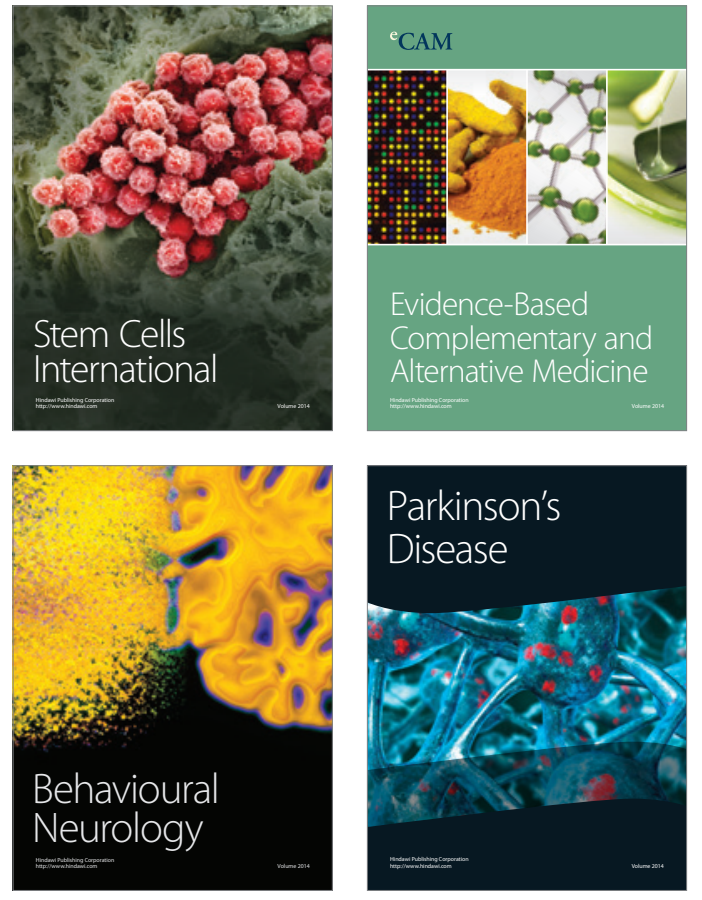
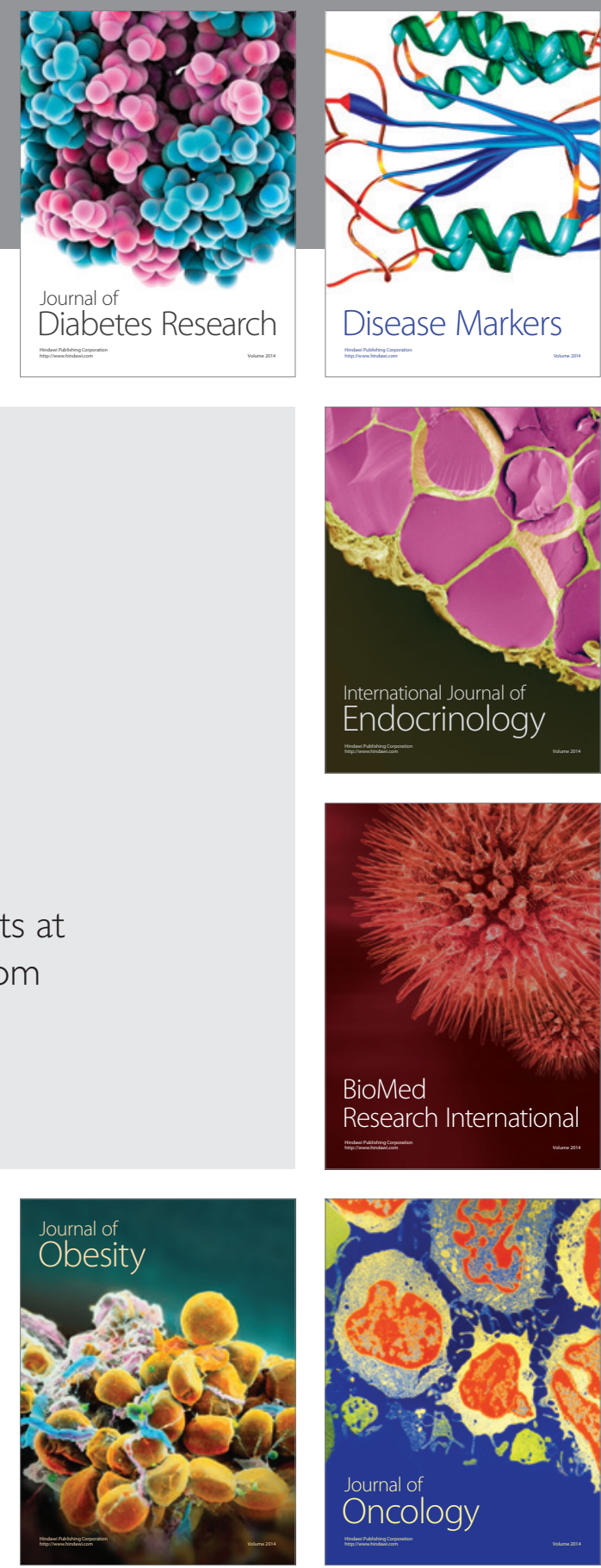

Disease Markers
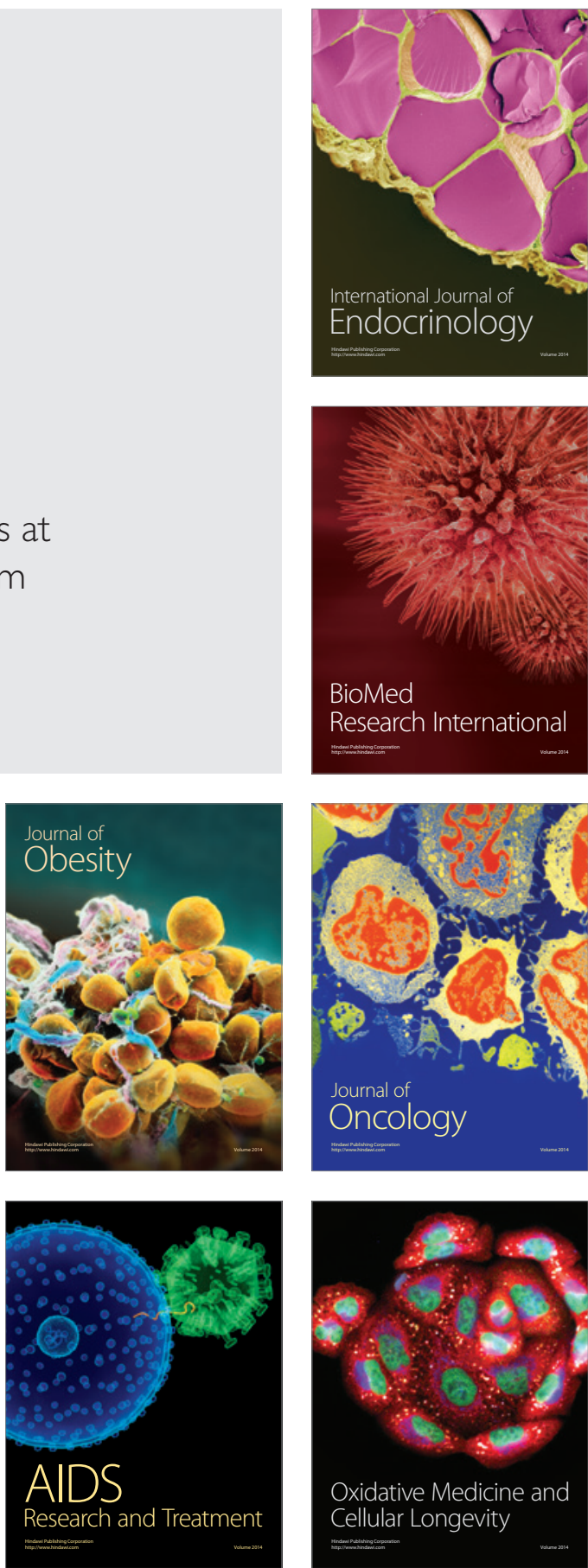